\title{
DILEMA PEMBELAJARAN ONLINE: ANTARA EFEKTIFITAS DAN TANTANGAN
}

\author{
Herianda Dwi Putra Siregar \\ UIN Sunan Kalijaga Jogjakarta, Indonesia \\ Email: heriandas@gmail.com
}

\begin{abstract}
Online learning requires a variety of preparations from various things, schools, parents and the government. Unfortunately, during online learning there are several phenomena that are important to note regarding its effectiveness, namely: unequal availability of internet service infrastructure networks. Competency gaps among teachers. Readiness of family (parents) in online learning. This article tries to elaborate on the dilemma of online learning. This paper concludes that it is very important and relevant for teachers and lecturers to equip themselves with the theory and principles of online learning before implementing them. Teachers and lecturers are required to continue learning to improve their understanding and competence related to online learning in all its variants. The success of teachers in conducting online learning in the Covid-19 pandemic situation is based on the ability of teachers to innovate in designing and concocting materials, learning methods, and what applications are in accordance with the materials and methods. Creativity is the key to success for a teacher to be able to motivate students to stay enthusiastic about learning online and not become a psychological burden.
\end{abstract}

Keyword: Online learning; Lecturers; Teachers; Students

Abstrak. Pembelajaran online membutuhkan berbagai persiapan dari berbagai hal, sekolah, orang tua dan pemerintah. Sayangnya, selama berlangsungnya pembelajaran online ada beberapa fenomena menjadi catatan penting terkait efektifitasnya, yaitu: tidak meratanya ketersediaan jaringan infrastruktur layanan internet. Kesenjangan kompetensi di kalangan guru. Kesiapan keluarga (orang tua) dalam pembelajaran online. Artikel ini mencoba mengelaborasi dilemma pembelajaran online. Tulisan ini menyimpulkan bahwa sangat penting dan relevan bagi guru dan dosen untuk membekali diri mereka dengan teori dan prinsip pembelajaran daring sebelum melaksanakannya. Guru dan dosen wajib terus belajar meningkatkan pemahaman dan kompetensi mereka terkait pembelajaran online ini dengan segala variannya. Keberhasilan guru dalam melakukan pembelajaran daring pada situasi pandemi Covid-19 ini berdasarkan kemampuan guru dalam berinovasi merancang, dan meramu materi, metode pembelajaran, dan aplikasi apa yang sesuai dengan materi dan metode. Kreatifitas merupakan kunci sukses dari seorang guru untuk dapat memotivasi siswanya tetap semangat dalam belajar secara online dan tidak menjadi beban psikis.

Kata Kunci: Pembelajaran online; Dosen; Guru; Siswa;

Permalink/DOI: https://doi.org/10.15408/mimbar.v37i2.18918 



\section{Pendahuluan}

Covid-19 merupakan infeksi virus baru yang mengakibatkan terinfeksinya 90.308 orang per tanggal 2 Maret 2020. Virus ini bermula di Wuhan, China pada 31 Desember 2019. Virus yang merupakan virus RNA strain tunggal positif ini menginfeksi saluran pernapasan. Penegakan diagnosis dimulai dari gejala umum berupa demam, batuk dan sulit bernapas hingga adanya kontak erat dengan negara-negara yang sudah terifinfeksi. Pengambilan swab tenggorokan dan saluran napas menjadi dasar penegakan diagnosis coronavirus disease. Penatalaksanaan berupa isolasi harus dilakukan untuk mencegah penyebaran lebih lanjut. (Yuliana, Wellness and Healthy Magazine, Vol. 2, No 1, Februari 2020).

Pandemi Corona Virus Disiases (Covid-19) yang melanda dunia -tidak terkecuali Indonesiatelah memberikan dampak negatif bagi kehidupan masyarakat dalam banyak faktor, mulai dari kesehatan, pendidikan, sosial kebudayaan, agama, ekonomi dan lain sebagainya. Dalam aspek kesehatan, hingga tanggal 24 November 2020, tercatat setidaknya ada 502.110 kasus, 422.386 kasus sembuh, 63.722 kasus aktif, dan 16.002 orang meninggal dunia akibat virus mematikan ini (https://covid19.kemkes.go.id/ diakses pada 24 November 2020.). Pandemi Covid-19 ini juga telah memberikan efek atau dampak negatif dalam banyak hal; aktivitas sosial dibatasi, ruang publik banyak ditutup, kegiatan keagamaan yang melibatkan banyak jemaah dilarang, aktivitas pendidikan -baik formal maupun informal - juga ditiadakan, banyak tenaga kerja dirumahkan (PHK), dan yang juga tak kalah parahnya adalah aktivitas perekonomian masyarakat menjadi lesu dan mandeg dan berakibat pada melambat atau menurunnya ekonomi nasional.

Kondisi ekonomi tersebut kemudian dinamakan dengan resesi, yakni periode penurunan ekonomi sementara di mana perdagangan dan aktivitas industri berkurang, umumnya kondisi ini ditandai dengan penurunan Pendapatan Domestik Bruto (PDB) dalam dua kuartal secara berturut-turut. Indonesia sendiri diprediksi akan mengalami resesi ekonomi pada bulan September 2020 ini. Hal tersebut secara tegas dinyatakan oleh Menkopolhukam Mahfud MD bahwa peluang resesi ekonomi Indonesia mencapai 99,9 persen. Ekonom dari lembaga Center of Reform on Economics (CORE) Yusuf Rendy Manilet mengatakan dampak resesi ekonomi paling terasa oleh masyarakat adalah pelemahan daya beli. Bahkan, kondisi tersebut sudah mulai tampak saat ini ketika pertumbuhan ekonomi mengalami kontraksi pada kuartal II 2020 hingga minus 5,32 persen. Jika Indonesia mengalami resesi, maka hal tersebut dapat menciptakan banyak pengangguran-pengangguran baru yang tersebar luas di berbagai wilayah. Karena sifat dari resesi tersebut adalah destruktif; terjadi ketidakseimbangan antara produksi dengan konsumsi, pertumbuhan ekonomi lambat bahkan merosot selama dua kuartal terturut- turut, nilai impor jauh lebih besar dibandingkan nilai ekspor, terjadi inflasi atau deflasi yang tinggi, dan tingkat pengangguran sangat tinggi (RI Terancam Masuk Jurang Resesi, Daya Beli PalingTerpukul, pada laman

https://www.cnnindonesia.com/ Senin, 31 Agustus 2020).

Menurut Menteri Ketenagakerjaan (Menaker) Republik Indonesia Ida Fauziyah angka pengangguran sebelum terjadi Pandemi Covid-19, tepatnya bulan Februari 2020 mengalami penurunan yakni dari yang awalnya 7.050.000 menjadi 6.800.000 orang. Namun selama Pandemi Covid-19 ini terjadi, pengangguran di Indonesia mengalami kenaikan yang sangat signifikan, yaitu mengalami penambahan sekitar 3.5 jutaan lebih, sehingga total keseluruhan pengangguran menjadi lebih dari 10 
jutaan. Kenaikan angka pengangguran tersebut disebabkan oleh gelombang Pemutusan Hubungan Kerja (PHK) besar-besaran yang dilakukan oleh banyak perusahaan (Pandemi Corona, Angka Pengangguran Tembus 10 Juta, pada laman https://finance.detik.com/ Selasa, 01 September 2020)

Selain sektor kesehatan dan ekonomi, pandemi ini juga memberikan dampak negatif bagi sektor pendidikan. Selama wabah pandemi ini berlangsung, aktivitas belajar-mengajar secara tatap muka di ruang kelas telah ditiadakan. Antara peserta didik dan guru mulai melakukan kebiasaan baru, yaitu proses Pembelajaran Jarak Jauh (PJJ): melalui medium e-learning atau belajar online. Sayangnya, selama berlangsungnya pembelajaran online ada beberapa fenomena menjadi catatan penting terkait efektifitasnya, yaitu: tidak meratanya ketersediaan jaringan infrastruktur layanan internet. Kesenjangan kompetensi di kalangan guru. Kesiapan keluarga (orang tua) dalam pembelajaran online.

\section{Dilema Pembelajaran Online}

Pembelajaran online atau Jarak Jauh (PJJ) merupakan proses belajar-mengajar yang mengandalkan adanya konektivitas antara peserta didik dengan pengajar secara daring atau online yaitu dengan memanfaatkan gawai untuk saling terhubung antara satu dengan yang lain. Pembelajaran online atau Jarak Jauh (PJJ) tersebut meniscayakaan bagi para penggunaan gawai untuk terhubung dengan jaringan internet selama proses belajar-mengajar berlangsung.

Pada mulanya, konsep Pembelajaran online atau Jarak Jauh (PJJ)dirancang untuk mengatasi kesenjangan pendidikan yang terjadi di Indonesia. Pembelajaran Jarak Jauh (PJJ) diharapkan dapat mengatasi masalah kesenjangan pemerataan kesempatan, peningkatan mutu, relevansi, dan efisiensi dalam bidang pendidikan yang disebabkan oleh berbagai hambatan seperti jarak, tempat, dan waktu. Untuk itu, penyelenggaraan Pembelajaran online atau Jarak Jauh (PJJ)harus sesuai dengan karakteristik pembelajar, tujuan pembelajaran dan proses pembelajaran. Dengan demikian, tujuan Pembelajaran online atau Jarak Jauh (PJJ) adalah untuk memberikan kesempatan pendidikan kepada warga masyarakat yang tidak dapat mengikuti pembelajaran konvensional secara tatap muka. Setidaknya ada empat (4) keuntungan atau manfaat kegiatan pembelajaran melalui internet, yaitu (Munir, 2009): a) Meningkatkan kadar interaksi pembelajaran antara pembelajar dengan pengajar (enhance interactivity); b) Memungkinkan terjadinya interaksi pembelajaran dari mana dan kapan saja (time and place flexibility); c) Menjangkau pembelajar dalam cakupan yang luas (potential to reach a global audience); d) Mempermudah penyempurnaan dan penyimpanan materi pembelajaran (easy updating of content as well as archivable capabilities).

Dalam sebuah hasil penelitian terbaru mengenai praktek kegiatan Pembelajaran online atau Jarak Jauh (PJJ) di Sekolah Menengah Atas (SMA) Negeri Unggulan M.H Thamrin Jakarta Timur, disebutkan bahwa dengan diterapkannya kebijakan Pembelajaran Jarak Jauh (PJJ) dari sekolah pada beberapa bulan ke belakang, terdapat fenoma baru yang terjadi yaitu: pertama, kesadaran yang tinggi dari orangtua akan sulitnya menjalankan profesi guru; kedua, meningkatnya kesadaran akan pendidikan ke orangtuaan yang selama ini banyak terabaikan; ketiga, proses pendidikan yang lebih multiliterat; keempat, meningkatnya pemahaman guru akan kondisi anak dan keluarganya; kelima, meningkatnya kesadaran literasi digital bagi guru, orangtua, dan siswa; dan keenam, guru dan siswa lebih banyak mengekplorasi materi-materi di luar buku paket (Jusuf, dkk., 2020). 
Namun dalam prakteknya, proses kegiatan Pembelajaran online atau Jarak Jauh (PJJ) tersebut, tentu tidak semua peserta didik dan para tenaga pengajar langsung terbiasa dengan kebiasaan baru tersebut, mengingat bahwa penggunaan alat teknologi bagi sebagian besar wilayah di pelosok negeri belum merata. Sebagain menganggap bahwa Pembelajaran online atau Jarak Jauh (PJJ) sebagai solusi yang efektif dan efisien. Namun tak sedikit pula dari mereka yang merasa keberatan terhadap praktik Pembelajaran Jarak Jauh (PJJ) tersebut dikarenakan banyak hal, mulai dari permasalahan yang bersifat subtansial maupun yang bersifat teknis.

Kendala subtansial dalam proses kegiatan Pembelajaran online atau Jarak Jauh (PJJ) semisal berikut ini:

\begin{tabular}{lll}
\hline \multicolumn{1}{c}{ Guru } & \multicolumn{1}{c}{ Siswa } & \multicolumn{1}{c}{ Orangtua } \\
- Guru kesulitan & - Siswa kesulitan & - Tidak semua \\
dalam & konsentrasi & orang tua \\
mengelola PJJ & belajar dari & mampu \\
dan cenderung & rumah dan & mendampingi \\
fokus pada & mengeluhkan & anak belajar di \\
penuntasan & beratnya & rumah karena \\
kurikulum. & penugasan soal & ada tanggung \\
- Waktu & dari guru. & jawab lainnya \\
pembelajaran & - Peningkatan & (kerja, urusan \\
berkurang & rasa stress dan & rumah, dsb). \\
sehingga guru & jenuh akibat & - Kesulitan \\
tidak mungkin & isolasi & orang tua \\
memenuhi & berkelanjutan & dalam \\
beban jam & berpotensi & memahami \\
mengajar. & menimbulkan & pelajaran dan \\
- Guru kesulitan & rasa cemas dan & memotivasi \\
komunikasi & depresi bagi & anak saat \\
dengan orang & anak. & mendampingi \\
tua sebagai & & belajar di \\
mitra di rumah. & & rumah \\
& & \\
\hline
\end{tabular}

Secara teknis, kendala Pembelajaran Jarak Jauh dapat kita temukan dalam hal pemanfaatan teknologi-lebih spesifiknya internet, gawai atau ponsel pintar, dan laptop-digunakan secara luas untuk mendukung program Pembelajaran online atau Jarak Jauh (PJJ). Salah satu penyedia jasa telekomunikasi terbesar di Indonesia mencatat bahwa peningkatan arus broadband sebesar 16\% selama krisis Covid-19, yang disebabkan oleh tajamnya peningkatan penggunaan platform Pembelajaran online atau Jarak Jauh (PJJ). Akan tetapi, gangguan terhadap sistem pendidikan tradisional ini telah merugikan siswa-siswa yang yang berasal dari keluarga prasejahtera dan yang berada di daerah pedesaan. Mereka adalah siswa yang, bahkan dalam kondisi normal, sudah menghadapi hambatan dalam mengakses pendidikan. Sekarang mereka perlu menghadapi hambatan tambahan yang muncul akibat ketidaksetaraan untuk mengakses infrastruktur teknologi. Perubahan mendadak dari metode tatap muka di ruang kelas menjadi pembelajaran jarak jauh di rumah juga menunjukkan kebutuhan peningkatan kapasitas guru. Beberapa penelitian menunjukkan bahwa kompetensi dalam penguasaan informasi, komunikasi, dan teknologi bagi guru-guru Indonesia tidak tersebar merata di seluruh wilayah. Terlebih 
lagi, ada kesenjangan kualitas pendidikan di seluruh wilayah di Indonesia, terutama antara Jawa dan luar Jawa, dan di antara kondisi- kondisi sosio-ekonomi. Akses internet yang tidak merata, kesenjangan kualifikasi guru, dan kualitas pendidikan, serta kurangnya keterampilan dalam penguasaan informasi, komunikasi, dan teknologi menjadi kerentanan dalam inisiatif Pembelajaran online atau Jarak Jauh (PJJ) di Indonesia (Azzahra, 2020).

Kesiapan guru dan siswa dalam memanfaatkan teknologi pembelajaran, khususnya pada jenjang pendidikan madrasah, relatif baik dan terus meningkat kualitasnya. Namun, muatan pembelajaran daring masih perlu terus disempurnakan agar lebih interaktif sehingga memungkinkan siswa dapat lebih terlibat (engaged) dalam proses pembelajaran. Daya dukung teknologi juga perlu terus ditingkatkan kualitasnya, sebagaimana fasilitas yang digunakan perusahaan-perusahaan penyedia konten (content provider). Kekurangsiapan guru dan manajemen sekolah serta minimnya deliberasi yang disebabkan terbatasnya waktu persiapan yang diberikan, menyebabkan kebijakan Pembelajaran online atau Jarak Jauh (PJJ) menuai kritikan dan/atau keluhan dari sebagian masyarakat, khususnya orang tua murid.

Sebagian masyarakat mengeluhkan Pembelajaran online atau Jarak Jauh (PJJ), sebagai kegiatan memindahkan aktivitas kelas dari sekolah ke rumah dengan beban/tugas yang bahkan lebih banyak. Selain itu, beberapa sekolah juga tetap melakukan kegiatan penilaian untuk kepentingan rapor kenaikan kelas pada kelas-kelas rendah. Adapun siswa pada kelas akhir tetap dibayangi dengan ujian kelulusan/UNBK. Ujian Akhir sepertinya hanya akan ditunda penyelenggaraan dan bukan dihentikan. Siswa dihadapkan pada kecemasan yang berganda; penularan wabah covid-19 dan tugas-tugas/Ujian Akhir Sekolah. Pendekatan Pembelajaran online atau Jarak Jauh (PJJ) yang digunakan sekarang menyebabkan siswa_-dan mungkin juga guru—kehilangan kesempatan untuk memahami dan mengerti dengan lebih dalam kejadian yang sedang dihadapi masyarakat dan bangsa saat ini. Mereka akan kehilangan momen penting untuk berefleksi guna menumbuhkan sikap solidaritas sosial, peduli, empati, dan peluang untuk memikirkan kontribusi yang dapat diberikan untuk membantu lingkungan masyarakat di masa sulit ini.

Dalam kondisi darurat ini, terdapat persoalan yang sangat kompleks untuk segera diatasi. Di antaranya adalah terkait dengan kemasan muatan Pembelajaran online atau Jarak Jauh (PJJ) yang idealnya sarat dengan penguatan literasi dan karakter. Konten diajarkan, selain untuk mengembangkan pengetahuan siswa (rote learning), juga digunakan sebagai medium dalam menumbuhkan dan memperkuat kemampuan literasi dan karakter. Selain itu, bagaimana dengan aspek penilai $\neg$ an yang memang haru tetap harus ada dan dilakukan. Idealnya, penilaian Pembelajaran online atau Jarak Jauh (PJJ) dilakukan bukan untuk menentukan standar pencapaian (attainment level) atau kepentingan nilai (assigning grade) semata. Penilaian dalam Pembelajaran online atau Jarak Jauh (PJJ) dilakukan mestinya dengan tujuan untuk membantu siswa agar dapat menemukan cara belajar yang lebih baik bagi dirinya pada setiap subjek yang dipelajari/diajarkan. Penilaian semacam ini disebut dengan penilaian formatif, yakni skor/nilai hasil sebuah aktivitas penilaian bukanlah standar pencapaian ataupun tujuan proses pembelajaran. Dan masih banyak lagi persoalan yang menuntut upaya keras dari semua pihak untuk sesegera mungkin menemukan solusi dan terobosan demi efektivitas Pembelajaran online atau Jarak Jauh (PJJ).

Sebenarnya dalam menghadapi situasi seperti ini, telah keluar Surat Keputusan Direktur Jenderal Pendidikan Islam Nomor 2791 Tahun 2020 Tentang Panduan Kurikulum Darurat pada Madrasah. 
Dalam SK tersebut disebutkan bahwa Kurikulum Darurat adalah kurikulum yang disusun dan dilaksanakan oleh satuan pendidikan pada masa darurat. Oleh karena itu semua aspek yang berkenaan dengan perencanaan pembelajaran, kegiatan pembelajaran dan penilaian hasil belajar disesuaikan dengan kondisi darurat yang terdapat dan dirasakan oleh setiap satuan pendidikan madrasah. Mempertimbangkan kondisi darurat setiap daerah dan madrasah berbeda, maka implementasi kurikulum darurat setiap satuan pendidikan bisa berbeda-beda sesuai dengan kondisi dan kebutuhan masing- masing. Untuk menghadapi situasi darurat ini, dalam SK tersebut disebutkan pula proses kegiatan pembelajaran yang dianjurkan dengan tiga metode, yaitu secara daring, semi-daring dan nondigital.

Kementerian Agama (Kemenag) Republik Indonesia (RI) sendiri telah melakukan berbagai macam kebijakan dan program dalam dalam upaya mendukung dan mempermudah proses kegiatan Pembelajaran online atau Jarak Jauh (PJJ), yaitu diantaranya: 1) Menguncurkan dana sebesar Rp 1,178 triliun dalam upaya mendukung dan mempermudah proses kegiatan Pembelajaran Jarak Jauh (PJJ) pendidikan agama akibat pandemi Covid-19. Bantuan tersebut diberikan untuk pendidikan agama Islam, Kristen, Katolik, Hindu, Buddha dan Konghucu. Bantuan dana ini sudah disepakati oleh Kementerian Keuangan (Kemenkeu) Republik Indonesia; 2) Meluncurkan Aplikasi E-Learning Madrasah, yaitu sebuah aplikasi gratis produk Madrasah yang ditujukan untuk menunjang proses pembelajaran di Madrasah dari mulai Madrasah Ibtidayah (MI), Madrasah Tsanawiyah (MTs) dan Madrasah Aliyah (MA), agar lebih terstruktur, menarik dan interaktif. E-learning Madrasah memiliki 6 role akses diantaranya: Operator Madrasah (Administrator) Guru Mata Pelajaran, Guru Bimbingan Konseling, Wali Kelas, Siswa, dan Supervisor (Kepala Madrasah dan jajarannya); 3) Madrasah Digital Belajar Jarak Jauh, yaitu program kerjasama antara Kemenag RI dengan beberapa perusahaan provider. Program ini bertujuan untuk pengembangan pendidikan para pelajar madrasah. Melalui program ini, kedua pihak memberikan bantuan sarana akses internet bagi para pelajar madrasah agar dapat mengikuti pembelajaran jarak jauh selama masa pandemi. Salah satunya adalah Telkomsel. Telkomsel memberikan bantuan kartu perdana dan kuota internet sebesar 10 GB kepada siswa madrasah yang membutuhkan. Selain itu, XL Axiata juga akan menyalurkan bantuan berupa kartu SIM gratis kepada para pelajar madrasah. Masing- masing kartu SIM sudah terisi kuota 30 GB yang bisa mereka manfaatkan selama dua bulan. Mekanisme penyaluran bantuan akan dilakukan dengan cara pendistribusian kartu SIM kepada madrasah di seluruh Indonesia.

Direktur Kurikulum, Sarana Prasarana, Kesiswaan dan Kelembagaan (KSKK) Madrasah Kemenag RI, Umar menyatakan, program Madrasah Digital Belajar Jarak Jauh ini diharapkan dapat menjangkau hingga lebih dari 74 ribu madrasah dengan 9,5 juta pelajar baik madrasah negeri maupun swasta yang tersebar di seluruh wilayah Indonesia. Selain masalah terkait daya beli pelajar atau orang tua mereka terhadap kuota data, banyak di antara madrasah tersebut berada di pelosok-pelosok daerah yang juga sulit mendapatkan sinyal seluler dan internet (www.xlaxiata.co.id, diakses pada 24 November 2020).

Dalam realisasinya, masih banyak ditemukan ketidakmerataan program bantuan dari pemerintah tersebut, khususnya di Kabupaten Tasikmalaya. Hal tersebut tentu sangat berpengaruh terhadap proses belajar- mengajar di tengah wabah pandemi ini. Keluhan tersebut semisal diutarakan oleh Perkumpulan Guru Madrasah (PGM) Indonesia Kabupaten Tasikmalaya yang mendesak pemerintah agar memenuhi 
anggaran bantuan bagi madrasah. Selain itu, guru madrasah juga mengeluhkan tidak adanya bantuan kuota internet siswa di lembaga pendidikan madrasah di sebagian besar sekolah madrasah di Tasikmalaya (https://didikpos.com/diakses pada 24 November 2020).

\section{Penutup}

Selama 8 bulan pembelajaran online berlangsung, banyak peristiwa yang terjadi, dari tidak kesiapan sekolah, orang tua dan pemerintah dengan infrastruktur pembelajaran online. pembelajaran online ini menimbulkan banyak masalah, terutama belum siapnya bangsa ini (lembaga pendidikan, masyarakat dan pemerintah) dalam menerapkan sistem pembelajaran online. Diantara masalah pembelajaran online di Indonesia adalah: Tidak meratanya ketersediaan jaringan infrastruktur layanan internet di Indonesia. Siswa yang tinggal di Pulau Jawa umumnya cukup beruntung karena relatif meratanya jangkauan provider internet, tetapi mereka yang di luar Jawa, apalagi Indonesia bagian timur, akses internet sangat memprihatinkan. Kementrian kominfo membeberkan dalam situs resminya dari 83.218 desa atau kelurahan di seluruh Indonesia, dipastikan yang sudah dapat menikmati jaringan 4G sebanyak 70.670 wilayah, jumlah tersebut sudah masuk wilayah 3T. Selain masalah infrastruktur jaringan internet yang belum merata di Indonesia, masalah pembelajaran online di Indonesia juga terkait dengan kesenjangan kompetensi di kalangan guru. Masih banyaknya guru dan dosen yang gagap tekhnologi walaupun saat ini sudah berada di era digital. Data dari beberapa penelitian semisal studi Widodo \& Riandi (2013 sebagaimana dikutip dalam Koh et al, 2018) menunjukkan bahwa kemampuan guru terkait penguasaan ICT sangat berbeda antar satu wilayah di Indonesia. Karena ketidaksiapan ini, di awal-awal Covid tak sedikit guru yang hanya sekedar memberikan tugas yang bertumpuk kepada siswa. Survey dari Komisi Perlindungan Anak Indonesia (KPAI) pada April 2020 menunjukkan bahwa mayoritas guru lebih banyak melakukan pembelajaran daring dengan memberikan penugasan kepada siswa melalui beberapa platform seperti whatsapp di awal- awal kewajiban belajar daring. Survey KPASI juga melaporkan bahwa 58,8\% guru yang disurvey mengaku bahwa mereka memberikan tugas yang sama untuk semua siswa tanpa mempertimbangkan kondisi sosial ekonomi dan personal siswa. Sementara materi Permasalahan lain yang muncul adalah tidak siapnya keluarga (orang tua) dalam pembelajaran online. Dukungan orang tua dalam pembelajaran online sangat dibutuhkan untuk kesuksesan dalam pembelajaran online. Khususnya anak yang masih duduk di sekolah kelas dasar dan menengah yang belum paham dan sadar untuk belajar secara mandiri dan butuh bimbingan dan arahan untuk memahami pelajaran yang diberikan.

Memperhatikan beberapa fenomena di atas, menjadi sangat penting dan relevan bagi guru dan dosen untuk membekali diri mereka dengan teori dan prinsip pembelajaran daring sebelum melaksanakannya. Guru dan dosen wajib terus belajar meningkatkan pemahaman dan kompetensi mereka terkait pembelajaran online ini dengan segala variannya. Keberhasilan guru dalam melakukan pembelajaran daring pada situasi pandemi Covid-19 ini berdasarkan kemampuan guru dalam berinovasi merancang, dan meramu materi, metode pembelajaran, dan aplikasi apa yang sesuai dengan materi dan metode. Kreatifitas merupakan kunci sukses dari seorang guru untuk dapat memotivasi siswanya tetap semangat dalam belajar secara online dan tidak menjadi beban psikis.

\section{Daftar Pustaka}


MIMBAR Agama Budaya, 37 (2), 2020

Munir, Pembelajaran Jarak Jaub Berbasis Teknologi, Informasi, dan Komunikasi, (Bandung: Alfabeta, 2009),

Heni Jusuf, dkk., "Pengaruh Pembelajaran Jarak Jauh bagi Siswa SMA di Era Covid-19," dalam Jurnal Kajian Ilmiah (KJI), Edisi Khusus, No. 1, Juli 2020,

Nadia Fairuza Azzahra, "Mengkaji Hambatan Pembelajaran Jarak Jauh di Indonesia di Masa Pandemi Covid-19," dalam Ringkasan Kebijakan Center for Indonesian Policy Studies, No 2, Mei 2020,

Madrasah Digital Belajar Jarak Jaub: XL Axiata- Kementerian Agama RI Kerja Sama Bantu Pelajar Madrasah, pada laman www.xlaxiata.co.id, diakses pada 24 November 2020.

Guru Madrasah Suarakan Aspirasi ke DPRD, Ketua PGM Tasik: Pemerintah Harus Adil, pada laman https://didikpos.com/ diakses pada 24 November 2020.

Pedoman Akademik Magister dan Doktor 2016- 2020, Sekolah Pascasarjana UIN Syarif Hidayatullah Jakarta,

Flam, Helena, and Debra King. Emotions and social movements. Routledge, 2007.

Kleres, Jochen. The Social Organization of Disease: Emotions and Civic Action. Taylor \& Francis, 2017Adisusilo, Sutarjo. (2002). Nasionalisme, Demokrasi, Civil Society. Jurnal Iman, Ilmu, Budaya, III, (9): 4. 